\title{
IMPLEMENTASI MANAJEMEN HUMAS DALAM MENINGKATKAN HUBUNGAN BAIK ANTARA SEKOLAH DENGAN WALI SISWA DI SD IT HARAPAN BUNDA SEMARANG JAWA TENGAH
}

Eka Khoiru Nisa, Denas Hasman Nugraha

STAI Terpadu Yogyakarta

\begin{abstract}
Implementasi manajemen humas dalam meningkatkan hubungan yang baik dengan masyarakat membutuhkan strategi yang tepat dalam merencanakan kegiatan sekolah yang bermanfaat bagi masyarakat. Masalah penelitian ini difokuskan pada Implementasi Manajemen Humas dalam Meningkatkan Hubungan Baik antara Sekolah dengan Wali Siswa. Penelitian ini bertujuan untuk mengetahui strategi yang dilakukan, bagaimana pelaksanaannya, dan juga implikasi pelaksanaannya dalam meningkatkan hubungan baik antara sekolah dengan wali siswa. Hasil penelitian yang peneliti lakukan, maka sampailah kepada kesimpulan bahwasannya strategi yang dilakukan manajemen Humas SD IT Harapan Bunda Semarang yaitu go public, bekerjasama dengan kesiswaan, penyusunan struktur organisasi, menggerakkan anggota-anggota organisasi dan berkoordinasi dalam mencapai tujuan yang ditetapkan lembaga, pengarahan dan pengawasan kepada personel sekolah, bekerjasama dengan tokoh masyarakat, bekerjasama dengan orang tua/ wali siswa, bekerjasama dengan komite sekolah,bekerjasama dengan organisasi masyarakat dan publikasi. Kemudian implementasi manajemen humas di SD IT Harapan Bunda yaitu hampir seluruh strategi yang direncanakan ada kerjasama antara pihak internal maupun eksternal, akan tetapi ada beberapa progam yang tidak terealisasi secara optimal yaitu pengelolaan website dikarenakan kesibukan dari penanggungjawab progam tersebut. Implikasi manajemen humas dalam meningkatkan hubungan baik antara sekolah dengan orang tua/ wali siswa SD IT Harapan Bunda berjalan dengan sangat baik hal ini ditunjukkan dengan data rerata skala tanggapan responden dengan jumlah 4,27. Selain itu banyaknya kegiatan-kegiatan bersama ortu/ wali siswa dalam meningkatkan hubungan baik.
\end{abstract}

Kata Kunci: Manajemen Humas, Hubungan Baik

\section{Pendahuluan}

Pendidikan merupakan hal yang sangat penting. Terutama di era globalisasi seperti sekarang ini, dimana persaingan semakin meningkat dan perkembangan teknologi yang semakin pesat mengharuskan terlahirnya generasi penerus bangsa yang mampu berfikir kritis dan yang lebih pintar sesuai dengan perubahan yang terjadi. Dan lembaga pendidikan baik formal maupun non formal dituntut untuk menjadi pen gemban amanat ilmu pengetahuan untuk menjawab.

Pada masa mendatang pendidikan merupakan investasi manusia (human investment) penting yang harus dirancang dan dibiayai secara lebih 
memadai, agar sumber daya manusia Indonesia mampu tumbuh dan bersaing dengan bangsa lain. Dalam sebuah proses pembangunan pendidikan harus ada upaya sadar dari pemerintah, masyarakat, dan keluarga semua perlu dilakukan secara terus menerus tanpa henti, supaya para generasi mampu merespon secara proaktif terhadap perkembangan jaman. ${ }^{1}$

Lembaga pendidikan adalah satu sub sistem dari beberapa sub sistem yang ada dalam masyarakat, keberadaan lembaga pendidikan tidak terlepas dari peran masyarakat, karena maju tidaknya sebuah lembaga pendidikan dalam semua jenjang dan level tergantung bagaimana lembaga pendidikan tersebut mampu menjalin kerjasama yang baik dengan masyarakat.

UU No. 20/ 2003 tentang Sisdiknas, pada Bab XV Pasal 54 dinyatakan bahwa: (1) Peran serta masyarakat dalam pendidikan meliputi peran serta perseorangan, kelompok, keluarga, organisasi profesi, pengusaha, dan organisasi kemasyarakatan dalam penyelenggaraan dan pengendalian mutu pelayanan pendidikan. (2) Masyarakat dapat berperan serta sebagai sumber, pelaksana, dan pengguna hasil pendidikan. (3) Ketentuan mengenai peran serta masyarakat sebagaimana dimaksud dalam ayat (1) dan ayat (2) diatur lebih lanjut dengan Peraturan Pemerintah. ${ }^{2}$

Manajemen humas menurut Ruslan yang dikutip oleh Zulkarnain Nasution adalah suatu proses dalam menangani perencanaan, pengorganisasian, mengkomunikasikan serta pengkoordinasian yang secara serius dan rasional dalam upaya pencapaian tujuan bersama dari organisasi atau lembaga yang diwakilinya. ${ }^{3}$ Dan untuk merealisasikan itu semua banyak hal yang harus dilakukan oleh humas dalam suatu lembaga pendidikan.

Di era globalisasi masyarakat akan lebih selektif dan berhati-hati dalam memilih lembaga pendidikan. Maka lembaga pendidikan harus berupaya untuk menciptakan citra sebaik mungkin di hadapan masyarakat. Namun pada masa sekarang semakin marak kasus yang terjadi pada lembaga pendidikan seperti fenomena geng pelajar di berbagai daerah dan sekolah yang melakukan kekerasan kolektif. Belum lagi kekerasan yang melibatkan guru dan siswa, termasuk kasus pelecehan seksual, rokok, narkoba dan miras yang pasang surut meramaikan peredaran berita di media massa. Kasus-kasus tersebut dapat menciptakan citra yang buruk pada lembaga pendidikan.

Bukan hal yang mudah untuk mengembalikan image positif. Pengembalian citra menjadi tantangan penting bagi lembaga pendidikan. Dalam hal ini humas atau public relations dalam lembaga pendidikan dapat membantu dalam mengembalikan citra suatu perusahaan atau lembaga

\footnotetext{
1Zulkarnain Nasution, Manajemen Humas di Lembaga Pendidikan,(Malang: UMM Press, 2010), hal. 2

2 UU RI No. 20 Tahun 2003 Tentang Pendidikan Nasional

${ }^{3}$ Zulkarnain Nasution, Manajemen Humas,... hal. 11 
pendidikan. Disebabkan fungsi humas atau public relations diantaranya mengelola opini publik guna menumbuhkan kemauan baik, partisipasi, dan keterlibatan dari publik dalam rangka menciptakan opini publik yang baik. ${ }^{4}$

Terciptanya opini publik didasarkan saling mempercayai adanya kesadaran akan kebutuhan bersama, tugas praktisi humas mengelola opini public agar kesan masyarakat terhadap lembaga pendidikan menjadi positif. Apabila kesan masyarakat positif terhadap lembaga pendidikan maka menciptakan kepercayaan masyarakat terutama orang tua sebagai wali siswa untuk memasukkan putra-putrinya pada lembaga pedidikan tersebut. Seperti halnya di SD IT Harapan Bunda Semarang, kepercayaan masyarakat terhadap sekolah terlihat dari siswa-siswi yang merupakan kakak beradik.

Peneliti memilih SD IT Harapan Bunda Semarang sebagai lokasi penelitian, mengingat SD IT tersebut merupakan sekolah yang banyak siswanya adanya kepercayaan wali siswa terhadap lembaga. Dengan adanya hubungan baik antara sekolah dengan wali siswa tumbuhlah kepercayaan wali siswa terhadap sekolah.

Atas dasar pemikiran di atas, peneliti merasa tertarik untuk membahas masalah tersebut khususnya yang berkenaan dengan implementasi manajemen humas terhadap hubungan baik antara sekolah dengan wali siswa. Untuk itu penulis mengajukan skripsi dengan judul Implementasi Manajemen Humas Dalam Meningkatkan Hubungan Baik Antara Sekolah Dengan Wali Siswa Di Sd It Harapan Bunda Semarang Jawa Tengah

\section{Tinjauan Pustaka}

1. Manajemen Humas Di Lembaga Pendidikan

Manajemen Humas terdiri dari dua kata yaitu, Manajemen dan Humas. Manajemen berasal dari kata "manage" atau "managiare" berarti melatih kuda dalam mengalahkan kakinya. Pengertian manajeman terkandung dua kegiatan yaitu kegiatan pikir (mind) dan kegiatan tindak laku (action). Menurut Ngalim Purwanto manajeman adalah proses untuk menyelenggarakan atau mengawasi suatu tujuan tertentu. Sedangkan Arifin Abdurrachman mengemukakan bahwa manajemen adalah kegiatan-kegiatan untuk mencapai sasaran-sasaran dan tujuan pokok yang telah ditentukan dengan menggunakan orang-orang pelaksana.

Kemudian Oemi Abdurrahman yang dikutip oleh B. Suryosubroto menjelaskan bahwa humas adalah kegiatan untuk menanamkan dan memperoleh pengertian, dukungan, kepercayaan, serta penghargaan pada dan dari publik suatu badan khususnya dan masyarakat pada umumnya. ${ }^{5}$ Hubungan masyarakat pada dasarnya

4 Ibid, hal. 17

5 B. Suryosubroto, Humas Dalam Dunia Pendidikan (Yogyakarta: Mitra Gama Widya, 2001), hal. 13 
merupakan bidang atau fungsi tertentu yang diperlukan setiap organisasi, sebagai mana dengan lembaga pendidikan. Public Relations, di lembaga pendidikan pada umumnya disebut hubungan masyarakat (humas).

Menurut kamus Fund and Wagnel pengertian humas adalah segenap kegiatan dan teknik/kiat yang digunakan organisasi atau individu untuk menciptakan atau memelihara suatu sikap dan tanggapan yang baik dari pihak luar terhadap keberadaan dan aktivitasnya.

Berdasarkan pengertian manajemen dan pengertian humas tersebut dapat ditarik pengertian kedua konsep tersebut yakni definisi manajemen humas. Menurut Ruslan manajemen humas yang dikutip oleh Zulkarnain Nasution adalah "suatu proses dalam menangani perencanaan, pengorganisasian, mengkomunikasikan serta pengkoordinasian yang secara serius dan rasional dalam upaya pencapaian tujuan bersama dari organisasi atau lembaga yang diwakilinya". 6

a. Tujuan dan Fungsi Manajemen Humas Di Lembaga Pendidikan

Tujuan humas sendiri bisa dirumuskan secara berbeda oleh setiap sekolah. Namun Sutisna memberikan penjelasan yang dikutip oleh Yosal Irianta bahwa tujuan humas adalah :

1) Mengembangkan pemahaman tentang maksud-maksud dan sasaran-sasaran dari sekolah

2) Menilai progam sekolah dalam kata-kata kebutuhan-kebutuhan yang terpenuhi

3) Mempersatukan orang tua murid dan guru-guru dalam memenuhi kebutuhan anak didik

4) Mengembangkan kesadaran tentang pentingnya pendidikan sekolah dalam era pembangunan

5) Membangun dan memelihara kepercayaan terhadap sekolah

6) Memberitahu masyarakat tentang pekerjaan sekolah

7) Mengerahkan bantuan dan dukungan bagi pemeliharaan dan peningkatan progam sekolah ${ }^{7}$

Mengenai fungsi dan peran humas, Effendy mengutip Bertrand R. Cranfield yang dikutip oleh Yosal Irianta menyebutkan fungsi humas adalah:

1) Mengabdi pada kepentingan umum

2) Memelihara komunikasi yang baik

3) Menekankan pada moral dan perilaku yang baik. ${ }^{8}$

${ }^{6}$ Ibid. hal. 11

7 Yosal Irianta, Manajemen Humas Sekolah (Bandung: Simbiosa Rekatama Media, 2013), hal. 28

8 Ibid, hal. 24

4 
Dari pengertian manajemen humas tersebut, fungsi pokok atau tahapan-tahapan dalam manajemen meliputi: perencanaan, pengorganisasian, penggerakan, pengkoordinasian, pengarahan, dan pengawasan dalam konteks kegiatan di lembaga pendidikan.

1) Fungsi Perencanaan

Perencanaan meliputi kegiatan menetapkan apa yang ingin dicapai, bagaimana mencapai, berapa lama, berapa orang yang diperlukan, dan berapa jumlah biayanya. Perencanaan ini dibuat sebelum suatu tindakan dilaksanakan. Perencanaan menurut Gibson, et al (1982) mencakup kegiatan menentukan sasaran dan alat sesuai untuk mencapai tujuan yang telah ditentukan. Perencanaan pada fungsi manajemen humas di lembaga pendidikan merupakan kesepakatan dan pengertian di antara personil lembaga pendidikan tentang apa yang harus dicapai organisasi.

Menurut jangkauan waktunya perencanaan dapat dibagi menjadi 3 (tiga) tahapan, yakni: (a) perencanaan jangka pendek (satu minggu, satu bulan, dan satu tahun), (b) perencanaan jangka menengah (perencanaan yang dibuat untuk jangka waktu 2 sampai 5 tahun), dan (c) perencanaan jangka panjang (perencanaan yang dibuat lebih dari 5 tahun)

Dalam menyusun perencanaan harus melibatkan banyak orang, yang harus menghasilkan progam-progam lembaga pendidikan, meliputi: progam yang berpusat pada siswa, kurikulum, pembelajaran, supervisi: keuangan, sarana dan prasarana, kepegawaian, layanan khusus, hubungan masyarakat, dan lain-lainnya.

2) Fungsi Pengorganisasian

Pengorganisasian diartikan sebagai kegiatan membagi tugas-tugas pada orang yang terlibat dalam kerjasama di lembaga pendidikan. Kegiatan pengorganisasian bertujuan menentukan siapa yang akan melaksanakan tugas sesuai dengan prinsip manajemen lembaga pendidikan. Fungsi perorganisasian di sini meliputi: pembagian tugas kepada masing-masing pihak, membentuk bagian, mendelegasikan, serta menetapkan wewenang dan tanggungjawab, sistem komunikasi, serta mengkoordinir kerja setiap karyawan di dalam suatu tim kerja yang solid dan terorganisir.

Langkah-langkah mendasar dalam mengorganisasi progamprogam di lembaga pendidikan menurut Gorton (1976) yaitu menentukan tugas, parameter waktu dan kebutuhan, jabatan dan tanggung jawab, merinci hubungan kewenangan, hubungan kepengawasan, hubungan komunikasi. Sedangkan prinsip pengorganisasian adalah organisasi lembaga pendidikan 
mempunyai tujuan yang jelas, tujuan lembaga pendidikan dapat dipahami dengan jelas dan diterima setiap tenaga pengajar dan karyawan, termasuk siswa dan orang tua siswa.

3) Fungsi Penggerakan

Menggerakkan dalam hal ini merangsang anggota-anggota organisasi melaksanakan tugas-tugas dengan antusias dan kemauan yang baik. Menurut Davis (1972) menggerakkan adalah kemampuan pemimpin membujuk orang-orang mencapai tujuantujuan yang telah ditetapkan dengan penuh semangat. Jadi, pemimpin lembaga pendidikan menggerakkan dengan semangat, pengikut juga bekerja dengan semangat.

4) Fungsi Pengkoordinasian

Pengkoordinasian berarti menjaga agar masing-masing tugas yang telah diberi wewenang dan tanggung jawab dikerjakan sesuai dengan aturan dalam mencapai tujuan. Menurut Gie (1983) pengkoordinasian adalah rangkaian aktivitas menghubung, menyatupadukan, dan menyelaraskan orang-orang dan pekerjaannya sehingga semuanya berlangsung secara tertib dan seirama menuju ke arah tercapainya tujuan tanpa terjadi kekacauan, percekcokan, dan kekosongan kerja.

Dari pengertian tersebut dapat ditegaskan, pengkoordinasian pada lembaga pendidikan adalah mempersatukan rangkaian aktivitas penyelenggaraan di lembaga pendidikan dan pembelajaran dengan menghubungkan dan menyelaraskan orang-orang dan pekerjaannya sehingga semua berlangsung secara tertib ke arah tercapainya maksud yang telah ditetapkan.

5) Fungsi Pengarahan

Pengarahan dilakukan agar kegiatan yang dilakukan bersama tetap melalui jalur yang ditetapkan, tidak terjadi penyimpangan yang dapat menimbulkan terjadinya pemborosan.

Menurut Sagala (2000) kegiatan pengarahan antara lain: (a) memberikan petunjuk dalam melaksanakan suatu kegiatan, (b) memberikan dan menjelaskan perintah, (c) memberikan kesempatan meningkatkan pengetahuan kepada pegawai agar dapat lebih efektif dalam melaksanakan tugas, (d) memberikan kesempatan ikut serta menyumbangkan tenaga dan pikiran, (e) memberikan koreksi agar setiap personil melaksanakan tugastugasnya secara efesien.Sebagai pengarah para pimpinan lembaga pendidikan tersebut berada pada tingkat pimpinan eksekutif tertinggi pada lembaga pendidikan tersebut.

6) Fungsi Pengawasan

Pengawasan dapat diartikan sebagai salah satu kegiatan untuk mengetahui realisasi perilaku tenaga pengajar dan 
karyawan dalam organisasi lembaga pendidikan. Secara umum pengawasan dikaitkan dengan upaya mengendalikan, membina dan pelurusan sebagai upaya pengendalian kualitas pendidikan. ${ }^{9}$

Fungsi komunikasi timbal balik (dua arah) di dalam suatu kegiatan manajemen pada suatu lembaga pendidikan sekarang ini biasanya diserahkan kepada pihak hubungan masyarakat (humas). Fungsi-fungsi manajemen humas dalam kegiatan pada lembaga pendidikan antara lain:

1) Mampu sebagai mediator dalam menyampaikan komunikasi secara langsung (komunikasi tatap muka) dan tidak langsung (melalui media pers) kepada pimpinan lembaga dan publik intern (dosen/guru, karyawan, dan mahasiswa/siswa) $\backslash$

2) Mendukung dan menunjang kegiatan-kegiatan yang berkaitan dengan mempublikasi lembaga pendidikan. Hal ini humas bertindak sebagai pengelola informasi kepada publik intern dan publik ekstern, seperti: menyampaikan informasi kepada pers, dan promosi.

3) Menciptakan suatu citra yang positif terhadap lembaga pendidikannya. ${ }^{10}$

Humas merupakan salah satu fungsi sebagai unsur pimpinan. Dengan demikian fungsinya adalah untuk menumbuhkan hubungan yang baik dan serasi antara public intern dan public ekstern dalam rangka memberikan pengertian, menumbuhkan motivasi dan partisipasi.

Eksistensi humas pada setiap lembaga/instansi merupakan suatu keharusan fungsional dalam rangka memperkenalkan kegiatan dan aktivitas kepada masyarakat.

b. Peran Humas Di Lembaga Pendidikan

Peran humas di lembaga pendidikan ke depan antara lain :

1) Membina hubungan harmonis kepada public internal (dalam lingkungan lembaga pendidikan, seperti dosen/ guru, tenaga administrasi, dan siswa), dan hubungan kepada public eksternal (di luar lembaga pendidikan, seperti : orang tua siswa, dan di luar lembaga pendidikan).

2) Membina komunikasi dua arah kepada publik internal (dosen/guru, karyawan, dan mahasiswa/ siswa) dan publik eksternal (lembaga luar/instantsi, masyarakat, dan media massa) dengan menyebarkan pesan, informasi dan publikasi hasil penelitian, dan berbagai kebijakan-kebijakan yang telah ditetapkan pimpinan.

9 Zulkarnain Nasution, Manajemen Humas di Lembaga Pendidikan (Malang: UMM Press, 2010), hal. 11

${ }^{10} \mathrm{Ibid}$, hal. 23 
3) Mengidentifikasi dan menganalisis suatu opini atau berbagai persoalan, baik yang ada di lembaga pendidikan maupun yang ada di masyarakat.

4) Berkemampuan mendengar keinginan atau aspirasi-aspirasi yang terdapat di dalam masyarakat.

5) Bersikap terampil dalam menterjemahkan kebijakan-kebijakan pimpinan yang baik. ${ }^{11}$

Dalam study Frinadyani yang dikutip oleh Yosal Irianta humas di sekolah menjalankan peran sebagai :

1) Penasihat ahli (expert presciber)

2) Fasilitator proses pemecah masalah (problem solving process facilitator)

3) Fasilitator komunikasi (communication fasilitator)

4) Teknisi komunikasi (communication technician) ${ }^{12}$

c. Progam Humas

Sesuai peranannya sebagai pengabdi untuk kepentingan umum, sebagai mediator antara pimpinan dengan publik, dan sebagai dokumentator, maka progam humas dititikberatkan pada :

1) Progam pelayanan

Progam ini beruapa pelayanan data/informasi baik secara lisan maupun tertulis, termasuk penyelenggaraan display tetap dan pameran.

2) Progam mediator

Progam ini berupa penerbitan berbagai media massa, peyelenggaraan konperensi pers, wisata pers, menjawab surat pembaca, menanggapi tajuk rencana yang negatif dan lain-lain.

3) Progam dokumentator

Progam ini berupa pembuatan dokumentasi film, foto rekaman (kaset audio dan video), transkip pidato dan lain-lain.

d. Implementasi Progam Humas Sekolah

Ketika semua yang sudah direncanakan secara strategis itu, maka perlu diimplementasikan. Dalam mengimplementasikan rencana strategis kehumasan akan ada dua hal yang penting yaitu rencana aksi dan pelaksanaan rencana aksi yang sudah ditetapkan. Selain itu diperlukan sumberdaya yang dimiliki sekolah, seperti sumberdaya manusia dan sumberdaya finansial.

Dengan demikian, implementasi rencana strategis berarti menjalankan berbagai tindakan yang perlu dilakukan untuk mencapai tujuan yang sudah diterapkan. Dalam implementasi rencana strategis akan diperlukan rencana aksi, keterlibatan pimpinan, komitmen terhadap implementasi rencana, alokasi

11Ibid, hal. 24

12Yosal Irianta, Manajemen Humas Sekolah (Bandung: Simbiosa Rekatama Media, 2013), hal. 140 
sumberdaya yang dibutuhkan untuk menjalankan rencana dan keterlibatan segenap warga organisasi. Komitemen kepala sekolah dan segenap warga sekolah dalam menjalankan rencana strategis itu merupakan hal yang sangat diperlukan.

Smith menunjukkan beberapa pertanyaan yang penting dijawab dalam implementasi progam/kegiatan kehumasan ini yang dikutip oleh Yosal Irianta. Ada 3 (tiga) hal yang mesti diperhatikan, yaitu: (1) bagaimana penjadwalan progam/kegiatan, (2) bagaimana anggaran yang disediakan untuk menjalankan progam, (3) siapa yang menjadi penanggung jawab pelaksanaan progam/kegiatan tersebut. ${ }^{13}$

Pada penjadwalan misalnya persoalan yang hendak diatasi adalah masalah keterlibatan orang tua dalam upaya meningkatkan mutu pembelajaran di sekolah yang mengharuskan sekolah banyak berkomunikasi dan menjalin relasi dengan orang tua/wali siswa, juga dengan guru dan tenaga kependidikan di sekolah. Maka disusunlah jadwal kegiatan berkomunikasi dengan orang tua/ wali siswa serta jadwal berkomunikasi dengan pendidik dan tenaga kependidikan.

Setelah itu dilakukan penunjukkan siapa yang akan bertanggung jawab terhadap kegiatan komunikasi yang dilakukan. Misalnya guru yang akan bertanggung jawab untuk berkomunikasi dan menjalin relasi dengan sesama pendidik dan tenaga kependidikan, ditetapkan pula guru lain untuk yang bertanggung jawab untuk memimpin proses komunikasi dengan orang tua/ wali siswa.

Bila komunikasi dengan orang tua/wali siswa dilakukan melalui pertemuan, diperlukan juga biaya untuk menyediakan konsumsi bagi peserta.

e. Pelaksanaan Progam Humas Sekolah

Menjalankan progam merupakan upaya mewujudkan perencanaan dalam kenyataan untuk mencapai tujuan lembaga. Sering dinyatakan, perencanaan yang baik merupakan sebagian dari pelaksanaan pekerjaan, separuh lagi pekerjaan itu dilaksanakan ketika progam dijalankan.

Dalam menjalankan progam/ kegiatan, hal yang penting dilakukan adalah melakukan komunikasi berkelanjutan dengan para pelaksana progam.

Nuansa komunikasi progam/kegiatan kehumasan sangat kental. Keterbukaan dan intensitas komunikasi diantara tim pelaksana kegiatan dan progam menjadi sangat penting. Kesalahpahaman atau salah menyampaikan informasi pada publik internal dan eksternal akan berdampak buruk bagi keseluruhan progam. Komunikasi di antara sesama anggota tim ini juga dilakukan 
untuk menumbuhkan semangat bekerja sekaligus untuk mengidentifikasi dan menyelesaikan permasalahan teknis operasional saat melaksanakan progam/kegiatan kehumasan sekolah.

Dengan keterbukaan komunikasi ini, pelaksana kegiatan dan progam dapat dengan mudah menyampaikan umpan balik untuk memperbaiki apa yang sudah dilakukan. Tenaga pelaksana kegiatan tidak terasa sungkan atau ragu untuk menyampaikan umpan balik pada pimpinannya. Tidak pula merasa perlu menyembunyikan sesuatu yang sesungguhnya perlu disampaikan untuk kebaikan pelaksanaan progam dan kegiatan itu.

f. Implementasi Strategi Humas Sekolah

Strategi humas sekolah merupakan penjabaran dari strategi sekolah dalam mencapai tujuan strategisnya. Oleh sebab itu, dalam menyusun rencana strategis humas akan mengacu sekaligus merupakan penjabaran rencana strategis sekolah. Humas sekolah sebagai fungsi manajemen sekolah menjalankan peran sebagai bidang yang menyelenggarakan komunikasi dan relasi untuk mencapai tujuan sekolah.

Secara umum, komunikasi bisa menjadi pendekatan dalam menjalankan perubahan yang diperlukan sekolah. Wandjiva mengutip Dransfied menyatakan, sistem komunikasi yang efektif dibutuhkan dalam mengimplementasikan strategi agar semua warga organisasi memiliki kesamaan visi, misi, tujuan dan nilai serta memahami dengan baik strategi dan bisa menghubungkan pemahaman itu dengan upaya yang dilakukannya. ${ }^{14}$

Humas sekolah bertanggung jawab terhadap kegiatan komunikasi yang dilakukan untuk menunjang implementasi strategi yang dipilih sekolah. Humas bertanggung jawab untuk menyiapkan materi komunikasi yang disebarluaskan kepada publik-publik sekolah untuk mendukung proses komunikasi yang diperlukan dalam menjalankan perubahan. Pada sisi lain, humas sekolah sendiri harus mengimplementasikan rencana strategis kehumasan sekolah yang merupakan penjabaran dari rencana strategis.

g. Media Humas Di Lembaga Pendidikan

Media sebagai salah satu alat dan sarana humas untuk menyampaikan informasi, publikasi, dan promosi kepada publik internal dan publik eksternal suatu lembaga pendidikan. Pada umumnya ada 2 (dua) jenis media yang sering digunakan dalam kegiatan humas. Media internal sasarannya ditujukan kepada peserta didik (mahasiswa/siswa), tenaga pengajar (dosen/guru), dan pegawai administrasi atau karyawan di lembaga pendidikan. Media eksternal sasarannya terdiri dari orang tua peserta didik, alumni, 
dunia industri atau usaha, instansi pemerintah dan swasta, serta masyarakat luas.

1) Jenis Media Internal Humas Di Lembaga Pendidikan

a. Warta atau Bulletin

b. Papan Informasi

c. Papan Foto

d. Spanduk dan Baliho

e. Presentasi Video dan Slide

f. Perangkat audio visual dapat digunakan untuk berbsgsi tujusn, deperti mensosialisasikan progam lembaga pendidikan kepada public internal.

g. Kaset video dan LCD

h. Komunikasi Tatap Muka

i. Acara Kekeluargaan

j. Klub Sosial

k. Literatur Pengenalan/ Informasi

1. Jaringan Telepon Internal

2) Jenis Media Eksternal Humas di Lembaga Pendidikan

Media eksternal sasarannya publik eksternal (ke luar). Guna menjangkau khlayak tertentu untuk mencapai tujuan humas. Karena itu sangat dibutuhkan adanya media humas eksternal yang berfungsi memberikan informasi dan penyampaian komunikasi kepada pihak atau lembaga lembaga luar. Media komunikasi eksternal itu sendiri memiliki berbagai bentuk antara lain:

a. Jurnal Eksternal

b. Media Audio Visual

c. Literatur Edukatif

d. Komunikasi Lisan

e. Pameran

f. Seminar dan Konferensi

g. Sponsor

h. Media Cetak

i. Media Elektronik

j. Media Tatap Muka atau Secara Langsung

k. Media Cetakan

1. Spanduk dan Umbul-umbul

m. Company Profile (Profil Lembaga Pendidikan) Merupakan buku yang memberikan informasi tentang profil dari lembaga pendidikan. Proses perencanaan tindakan, strategi penyampaian pesan (komunikasi).

n. Special Event (kegiatan khusus dalam Humas)

o. Media Internet

7) Hubungan Baik antara Sekolah dengan Wali Siswa 
a. Pengertian Hubungan Baik, Sekolah dan Wali Siswa

Hubungan menurut Kamus Besar Bahasa Indonesia adalah "keadaan berhubungan: sekolah dengan sekolah lain cukup harmonis"15. Hubungan atau communication secara sederhana dapat diartikan sebagai proses penyampaian berita dari seseorang ke orang lain. ${ }^{16}$ Pengertian baik menurut Kamus Besar Bahasa Indonesia adalah elok; patut; teratur (apik, rapi, tidak ada celanya) ${ }^{17}$. Sekolah adalah salah satu organisasi pendidikan yang mempunyai suatu kekuatan untuk membantu dan mengantarkan peserta didik menuju cita-cita yang diharapkan. Sekolah yang baik adalah sekolah yang bisa mencetak siswa-siswa yang berprestasi tinggi dan dapat memanfaatkan guru-guru yang berkualitas baik serta mendapatkan kepercayaan dari masyarakat sekitar sehingga mutu pendidikan menjadi terjamin dengan meningkatnya prestasi siswa didik sesuai dengan yang diharapkan. ${ }^{18}$

Sedangkan pengertian orang tua menurut Kamus Besar Bahasa Indonesia orang tua adalah "ayah ibu kandung, orang yang dianggap tua, orang yang dihormati"19, dari pengertian tersebut dapat diambil kesimpulan bahwa pengertian orang tua dalam penelitian ini adalah ayah dan ibu dari anak (jika anak itu tinggal bersama ayah dan ibu) atau orang lain yang bertanggung jawab atas pendidikan anak tersebut, wali siswa atau orang tua asuh atau jika anak tersebut tinggal bersama wali yang mendidik anak menjadi manusia yang bermanfaat bagi keluarga, masyarakat, dan warga negara yang baik.

Dengan demikian perhatian orang tua dapat dinyatakan sebagai perhatian ayah dan ibu. Orang tua merupakan pendidik yang pertama dan paling utama, sedangkan guru di sekolah hanya merupakan pendidik setelah orang tua. Berkaitan dengan pengertian perhatian yang dipaparkan diatas, intensitas perhatian orang tua adalah tingkat keseringan perhatian orang tua yang ditujukan pada kegiatan belajar anak, memberikan bimbingan

15 Departemen Pendidikan Nasional, Kamus Besar Bahasa Indonesia Pusat Bahasa, (Jakarta: PT.Gramedia Pustaka Utama,2008), hal. 558

16 http://lib.uin-malang.ac.id/files/thesis/fullchapter/00160043.pdf diakses pada Jum'at, 09/10/2015 jam 14.20 WIB

17 Departemen Pendidikan Nasional, Kamus Besar Bahasa Indonesia Pusat Bahasa, (Jakarta: PT. Gramedia Pustaka Utama,2008), hal. 118

${ }^{18}$ http://lib.uin-malang.ac.id/files/thesis/fullchapter/00160043.pdf diakses pada Jum'at, 09/10/2015 jam 14.20 WIB

19 Departemen Pendidikan Nasional, Kamus Besar Bahasa Indonesia Pusat Bahasa, (Jakarta: PT. Gramedia Pustaka Utama,2008), hal. 1053

12 
belajar, memperhatikan dan memenuhi kebutuhan alat-alat penunjang pembelajaran. ${ }^{20}$

b. Cara membangun hubungan yang baik antara sekolah dengan wali siswa adalah :

1) Adanya kerja sama antara sekolah dengan wali siswa

2) Rapat

3) Pertemuan dan Musyawarah

4) Kunjungan ke rumah (home visit)

5) Pawai atau karnaval

6) Acara tutup tahun

7) Kegiatan sosial masyarakat 21

c. Upaya-upaya dalam berhubungan dengan Masyarakat

Dalam membina hubungan dengan masyarakat, maka humas harus menggunakan pendekatan-pendekatan yang strategis agar dapat menggalang partisipasi masyarakat yaitu dapat dilakukan dengan antara lain:

1) Melibatkan masyarakat dalam berbagai progam dan kegiatan di sekolah yang bersifat sosial kemasyarakatan.

2) Mengidentifikasi tokoh masyarakat, yaitu orang-orang yang mampu mempengaruhi masyarakat pada umumnya.

3) Melibatkan tokoh masyarakat tersebut dalam berbagi program dan kegiatan sekolah yang sesuai dengan minat mereka.

4) Memilih waktu yang tepat untuk melibatkan masyarakat sesuai dengan kondisi dan perkembangan masyarakat.

Beberapa aktivitas para pengajar yang berkaitan dengan usaha memajukan hubungan lembaga dengan masyarakat ialah :

1) mengunjungi rumah-rumah dalam rangka memecahkan masalah pendidikan atau membina persahabatan.

2) Menunjukkan sikap positif terhadap orang tua tentang kemajuan putranya secara tertulis atau lewat telepon.

3) Bekerja sama dengan masyarakat mengembangkan kebijakan pekerjaan rumah para putra mereka.

4) Berusaha mencari jalan untuk memperbaiki komunikasi antara lembaga dengan masyarakat yang trampil dengan cara memanfaatkannya sebagai nara sumber. ${ }^{22}$

Hubungan sekolah dengan masyarakat serta hubungan sekolah dengan orang tua murid, pada hakikatnya adalah suatu

20Siti Aminatun, Kontribusi Manajemen Hubungan Masyarakat (Humas) Dalam Meningkatkan Kepercayaan Wali Siswa Kepada SDIT BIAS Giwangan Yogyakarta. Yogyakarta: Perpustakaan Sekolah Tinggi Agama Islam Terpadu (STAIT) Yogyakarta, 2014.

${ }^{21}$ Ibid, hal. 41

22 Dr. Made Pidarta, Manajemen Pendidikan Indonesia (Jakarta: PT Bina Aksara Jakarta, 1988), hal. 206 
pembinaan, penumbuhan, dan pengembangan murid-murid di sekolah. Oleh sebab itu, hubungan tersebut perlu dibina, dibangun, dan dipelihara sebaik-baiknya karena merupakan satu jembatan saling pengertian sehingga mereka dapat berpartisipasi secara positif dan dapat memberikan dukungan moral dan material secara ikhlas.

Kerja sama dan partisipasi masyarakat dalam bidang pendidikan memerlukan kesdaran masyarakat akan arti penting peran mereka dalam peningkatan kualitas pendidikan. Untuk menghasilkan kerja sama dan tingkat partisipasi yang tinggi, pertama kali sekolah harus menyadarkan masyarakat akan peran mereka dalam pembangunan pendidikan. Setelah kesadaran itu tercapai, sekolah mesti melakukan komunikasi secara lebih intensif dengan masyarakat agar kesadaran masyarakat berbuah dukungan. Untuk itu manajemen hubungan sekolah masyarakat perlu dikelola dengan lebih baik.

\section{Metode Penelitian}

1. Jenis Penelitian

Jenis penelitian ini apabila dilihat berdasarkan fungsinya, yaitu termasuk penelitian dasar. Jika ditinjau berdasarkan sifat permasalahannya, yaitu penelitian deskriptif. Ditinjau berdasarkan tempat dan latar, yaitu penelitian lapangan. Penelitian ini juga menggunakan pendekatan kualitatif.

2. Tempat dan Waktu

Tempat yang dipilih dalam penelitian ini adalah SD IT Harapan Bunda Semarang. Waktu penelitian yang dilakukan 12 Februari 2016-selesai akhir penelitian dan disesuaikan dengan jadwal akademik SD IT Harapan Bunda Semarang.

3. Sampel dan Sumber Data

Penelitian ini menggunakan teknik purposive sampling. Penelitian ini juga menggunakan random sampling. Untuk menjawab rumusan masalah tersebut dibutuhkan data primer yaitu Personalia Bagian Humas SD IT Harapan Bunda Semarang dan data sekunder penelitian ini menggunakan dokumentasi

4. Instrumen Penelitian

Dalam penelitian kualitatif instrumen utama adalah peneliti sendiri, yang berfungsi menetapkan fokus penelitian, memilih informan sebagai sumber data, melakukan pengumpulan data, menilai kualitas data, analisis data, menafsirkan data dan membuat kesimpulan atas temuannya.

5. Teknik Pengumpulan Data

Dalam penelitian ini penulis menggunakan beberapa metode penelitian:

1) wawancara, 2) angket, 3) observasi, dan study dokumenter. 
6. Teknik Analisis Data

Teknik analisis data menggunakan langkah : 1) reduksi data (data reduction), 2) penyajian data (data display), 3) analisis data secara kualitatif, dan verification (conclution drawing).

7. Keabsahan Data

Keabsahan data menggunakan teknik triangulasi yaitu : 1) triangulasi sumber, 2) triangulasi teknik, 3) pengumpulan data, dan waktu.

\section{Hasil Penelitian}

Hasil wawancara tersebut adalah kegiatan apa saja yang dapat meningkatkan hubungan baik antara sekolah dengan wali siswa, dan dimensi tersebut adalah peran humas. Wawancara disusun berdasarkan pokok penelitian yang diteliti mengenai implementasi manajemen humas dan kegiatan yang meningkatkan hubungan baik antara sekolah dengan wali siswa di SDIT Harapan Bunda Semarang. Untuk mengetahui strategi apa saja yang dilakukan humas dalam meningkatkan hubungan kepada wali siswa SD IT Harapan Bunda Semarang dan bagaimana implementasi manajemen humas dalam aspek fungsi manajemen humas dan fungsi humas serta peran humas yang ada di sekolah tersebut. Berikut penulis sajikan hasil angket dari 5 aspek, masing-masing aspek ada yang 3,4 bahkan 5 item pernyataan yang diberikan kepada 240 responden.

Dari hasil analisis yang bersumber dari angket dan data-data yang diperoleh yaitu terkumpul 210 angket dari 240 angket yang dibagikan, maka adapun hasilnya adalah sebagai berikut :

Tanggapan Responden Tentang Hubungan Sekolah dengan Orang Tua/ Wali Siswa

\begin{tabular}{|c|l|c|c|c|c|c|}
\hline No & \multicolumn{1}{|c|}{ Indikator } & \multicolumn{5}{c|}{ Frekuensi Skala } \\
\cline { 3 - 7 } & & $\mathbf{5}$ & $\mathbf{4}$ & $\mathbf{3}$ & $\mathbf{2}$ & $\mathbf{1}$ \\
\hline 1 & $\begin{array}{l}\text { Pertemuan komite sekolah yang } \\
\text { dilaksanakan 1 tahun 2 Kali }\end{array}$ & 45 & 121 & 36 & 5 & 3 \\
\hline 2 & Kegiatan seminar komite/ lainnya & 92 & 106 & 12 & 0 & 0 \\
\hline 3 & Lomba antar komite kelas & 35 & 124 & 44 & 6 & 1 \\
\hline 4 & $\begin{array}{l}\text { Komite menginformasikan kepada } \\
\text { pihak sekolah terkait dengan hal-hal } \\
\text { yang bersifat masukan dari orang tua/ } \\
\text { wali siswa }\end{array}$ & 107 & 80 & 20 & 3 & 0 \\
\hline 5 & $\begin{array}{l}\text { Pembahasan Rencana Anggaran } \\
\text { Pendapatan dan Belanja Sekolah } \\
\text { (RAPBS) dan Rencana Kerja Sekolah } \\
\text { (RKS) antara komite dengan sekolah }\end{array}$ & 80 & 103 & 23 & 4 & 0 \\
\hline 6 & $\begin{array}{l}\text { Kegiatan Baksos yang dilaksanakan 2-3 } \\
\text { kali setiap tahunnnya }\end{array}$ & 73 & 110 & 22 & 5 & 0 \\
\hline 7 & Kegiatan cek kesehatan gratis & 97 & 85 & 24 & 4 & 0 \\
\hline
\end{tabular}




\begin{tabular}{|c|c|c|c|c|c|c|}
\hline 8 & $\begin{array}{l}\text { Kegiatan Bazar yang melibatkan orang } \\
\text { tua/ wali siswa }\end{array}$ & 58 & 119 & 31 & 2 & \\
\hline 9 & $\begin{array}{l}\text { Kegiatan Ta'lim rutin setiap dua pekan } \\
\text { sekali }\end{array}$ & 98 & 100 & 10 & 2 & 0 \\
\hline 10 & $\begin{array}{l}\text { Kegiatan silaturahmi yaitu Anjangsana } \\
\text { (Menyampaikan perkembangan anak) }\end{array}$ & 89 & 89 & 23 & 7 & 2 \\
\hline 11 & $\begin{array}{l}\text { Kegiatan Home Visit (ketika ada siswa } \\
\text { sakit, wali siswa sakit dan wali siswa } \\
\text { melahirkan) }\end{array}$ & 105 & 87 & 15 & 2 & 1 \\
\hline 12 & $\begin{array}{l}\text { Pemberian potongan SPP untuk } \\
\text { masyarakat yang menyekolahkan } \\
\text { anaknya }\end{array}$ & 78 & 106 & 18 & 6 & 2 \\
\hline 13 & $\begin{array}{l}\text { Memberikan informasi terkait } \\
\text { Penerimaan Siswa Baru (PSB) kepada } \\
\text { masyarakat (orang tua/ wali siswa) }\end{array}$ & 77 & 118 & 14 & 0 & 1 \\
\hline 14 & $\begin{array}{l}\text { Pemberitahuan rapat yang melibatkan } \\
\text { orang tua/ wali siswa melalui surat } \\
\text { resmi }\end{array}$ & 103 & 99 & 8 & 0 & 0 \\
\hline 15 & $\begin{array}{l}\text { Mengundang murid-murid TK dari } \\
\text { berbagai sekolah dalam acara open } \\
\text { house yang bertujuan untuk mencari } \\
\text { anak didik baru dan menciptakan citra } \\
\text { yang positif suatu lembaga }\end{array}$ & 95 & 104 & 11 & 0 & 0 \\
\hline 16 & $\begin{array}{l}\text { Guru membina hubungan harmonis } \\
\text { kepada guru, siswa maupun } \\
\text { masyarakat (orang tua/ wali siswa) }\end{array}$ & 125 & 78 & 7 & 0 & 0 \\
\hline 17 & $\begin{array}{l}\text { Guru membina komunikasi dua arah } \\
\text { seperti menyebarkan pesan, informasi } \\
\text { dan publikasi dari kebijakan kepala } \\
\text { sekolah }\end{array}$ & 108 & 86 & 16 & 0 & 0 \\
\hline 18 & $\begin{array}{l}\text { Guru menganalisis suatu opini/ } \\
\text { berbagai persoalan yang ada di } \\
\text { lembaga maupun di masyarakat }\end{array}$ & 64 & 109 & 37 & 0 & 0 \\
\hline 19 & $\begin{array}{l}\text { Guru mendengarkan keinginan atau } \\
\text { aspirasi dari masyarakat (orang tua/ } \\
\text { wali siswa) }\end{array}$ & 91 & 97 & 22 & 0 & 0 \\
\hline \multicolumn{2}{|c|}{ ¿ Skala Penilaian } & 1620 & 1921 & 393 & 46 & 10 \\
\hline \multicolumn{2}{|c|}{ Total Penilaian $(\mathrm{TP})=\sum($ Fi.Si $)$} & \multicolumn{5}{|c|}{17065} \\
\hline \multicolumn{2}{|c|}{ Rerata Skala $=\frac{\sum F i . S i}{\sum F i}$} & \multicolumn{5}{|c|}{4,27} \\
\hline \multicolumn{2}{|c|}{ Kriteria Aspek Instruksional } & \multicolumn{5}{|c|}{ Sangat Baik } \\
\hline
\end{tabular}

Sumber: Angket Responden 
Keterangan:

Fi: Frekuensi jumlah responden yang menjawab pada skor tertentu

Si: Skor/ Nilai

$\sum$ : Menujukkan jumlah

Dari hasil penelitian yang dilakukan kepada sejumlah wali siswa yang menjadi sampel, peneliti melakukan analisis data yang merupakan bagian yang penting dalam metode ilmiah untuk menjawab masalah penelitian. Berdasarkan analisis data tersebut peneliti dapat interprestasikan bahwa kegiatan yang mampu meningkatkan hubungan antara sekolah dengan orang tua/ wali siswa dan juga peran humas di suatu lembaga pendidikan SD IT Harapan Bunda Semarang termasuk kriteria aspek intruksional sangat baik dengan rata-rata 4,27. Hal ini dimasudkan untuk mengetahui implementasi manajemen humas dalam meningkatkan hubungan baik antara sekolah dengan orang tua/ wali siswa secara keseluruhan.

\section{Analisis Hasil Penelitian}

1. Strategi Manajemen Humas SD IT Harapan Bunda dalam Meningkatkan Hubungan Baik antara Sekolah dengan Wali Siswa

SD IT Harapan Bunda menyusun strategi yaitu dengan sebagai berikut:

a. Strategi yang diterapkan pada masyarakat internal SD IT Harapan Bunda Semarang Jawa Tengah

Paparan hasil wawancara terkait hubungan masyarakat internal SD IT Harapan Bunda Semarang meliputi masyarakat yang ada di dalam sekolah seperti hubungan pimpinan dengan karyawan, hubungan sesama guru, hubungan guru dengan siswa.

1) Go public

Salah satu kegiatan yang dilaksanakan khusus untuk siswa yaitu go public artinya membawa anak-anak untuk mengikuti lomba yang ada di luar.

2) Bekerjasama dengan bagian kesiswaan

Bagian humas bekerjasama dengan bagian kesiswaan ketika membawa siswa/ i mengikuti lomba yang ada di luar karena bagian kesiswaan bertugas mendampingi anak.

3) Penyusunan struktur organisasi kehumasan

Salah satu fungsi pengorganisasian di bagian humas SD IT Harapan Bunda yaitu penyusunan struktur organisasi. Bagian humas terdiri dari 4 staf yaitu koordinator humas, bagian internal, bagian eksternal dan bagian komite sekolah.

4) Menggerakkan anggota-anggota organisasi dan berkoordinasi dalam mencapai tujuan yang ditetapkan lembaga 
Cara bagian humas SD IT Harapan Bunda untuk menggerakkan anggota-anggota organisasi tidak hanya menggunakan lisan saja justru lebih banyak menggunakan teknologi karena dengan berkembangnya jaman teknologi sekarang semakin canggih. Selain itu juga dalam bentuk kegiatan yaitu ketika rapat mingguan yang dilaksanakan pada hari Jum'at. ${ }^{23}$ Sedangkan koordinasi dapat diwujudkan dengan cara rapat baik rapat jangka pendek dan rapat jangka panjang. SD IT Harapan Bunda mengadakan rapat jangka pendek dalam artian rapat mingguan yang dilaksanakan setiap hari Jum'at. Sedangkan untuk rapat jangka panjang setiap 6 bulan sekali biasa disebut dengan rapat kerja.

5) Pengarahan kepada personel sekolah

Pengarahan dilakukan agar kegiatan yang dilakukan bersama tetap melalui jalur yang ditetapkan. Kegiatannya seperti memberikan petunjuk dalam melaksanakan suatu kegiatan, memberikan dan menjelaskan perintah.

6) Pengawasan kepada personel sekolah

Pengawasan dapat diartikan sebagai salah satu kegiatan untuk mengetahui realisasi perilaku tenaga pengajar dan karyawan dalam organisasi lembaga pendidikan. Pengawasan di SD IT Harapan Bunda dengan cara evaluasi pekanan.

b. Strategi yang diterapkan pada masyarakat eksternal SD IT Harapan Bunda Semarang Jawa Tengah

1) Bekerjasama dengan tokoh masyarakat

Salah satu pendekatan untuk menggalang partisipasi masyarakat yaitu membangun kerjasama dengan tokoh masyarakat, untuk itu SD IT Harapan Bunda membangun kerjasama dengan tokoh masyarakat salah satunya melalui kegiatan seminar parenting.

2) Bekerjasama dengan Orang tua/ wali siswa

Salah satu cara membangun hubungan baik antara sekolah dengan orang tua/ wali siswa adalah adanya kerjasama antara keduanya. Kerjasama yang sudah direncanakan oleh humas SD IT Harapan Bunda yaitu berupa kegiatan-kegiatan. Agar kegiatan-kegiatan tersebut sesuai dengan tujuan lembaga maka sekolah senantiasa berkomunikasi, berorganisasi dan juga berkoordinasi dengan orang tua/ wali siswa.

3) Bekerjasama dengan Komite Sekolah

Sebagai konsekuensi untuk mengakomodasi aspirasi, harapan dan kebutuhan stakeholder sekolah, maka perlu dikembangkan adanya wadah untuk menampung dan menyalurkannya. Wadah tersebut berfungsi sebagai forum di mana representasi para stakeholder sekolah terwakili secara proposional. Wadah ini diberi nama 
komite sekolah. Menurut penjelasan Kabid Humas SD IT Harapan Bunda bahwa ada hubungan baik antara sekolah dengan orang tua/ wali siswa melalui komite karena komite sering menyambangi atau menginformasikan kepada humas mengenai persoalan-persoalan yang ada di sekolah maupun masyarakat. ${ }^{24}$ Selain itu juga untuk memperkuat organisasi antara sekolah dengan wali siswa. ${ }^{25}$

4) Bekerjasama dengan organisasi-organisasi masyarakat

Sebagai sebuah lembaga swasta SD IT Harapan Bunda Semarang juga mejalin kerjasama dengan organisasi masyarakat seperti media penyampaian informasi sekolah, perusahaan yang menjadi sponsor untuk acara-acara sekolah, pendiri-pendiri sekolah, lembaga kemanusiaan PKPU.

c. Publikasi

Strategi yang direncanakan oleh humas SD IT Harapan Bunda Semarang selanjutnya yaitu publikasi dengan cara menberikan informasi terkait penerimaan siswa baru kepada masyarakat (orang tua/ wali siswa), menyebarkan informasi melalui media sosial.

2. Pelaksanaan Manajemen Humas SD IT Harapan Bunda dalam Meningkatkan Hubungan Baik antara Sekolah dengan Wali Siswa.

Dalam setiap kegiatan yang dilaksanakan SD IT Harapan Bunda selalu ada komunikasi baik itu dengan pihak internal maupun eksternal. Setiap tahun SD IT Harapan Bunda mempunyai tahapan dalam membawa anak-anaknya untuk mengikuti lomba yang ada di luar sekolah. Pelaksanaan bekerjasama dengan kesiswaan yaitu ketika membawa anak-anaknya mengikuti lomba-lomba yang ada di luar karena kesiswaan bertugas mendampingi selain itu juga membutuhkan verifikasi internal supaya anak-anak benar-benar siap ketika mengikuti lomba. Struktur organisasi kehumasan di SD IT Harapan Bunda Semarang terdiri dari 4 staf dan masing-masing staf mempunyai tugas. Untuk koordinator humas yaitu pak Dany Arif Ardiyanto, S.Pd.I beliau membimbing staf-staf yang ada di humas, selain itu juga beliau kadang mewakili kepala sekolah mengenai informasi atau perintah ketika kepala sekolah ada dua urusan yang bersamaan. Kemudian media eksternal yaitu pak Nurhadi beliau fokus pada bagian eksternal seperti menginformasikan/ mempublikasikan kegiatan yang ada di sekolah ke luar melalui media sosial seperti facebook, website, dsb. Untuk eksternal yang lain yaitu komite sekolah, untuk bagian komite sekolah ada bu Rodhiati, S.Pd beliau fokus pada kegiatan yang berhubungan dengan komite sekolah artinya lebih sering brhubungan dengan orang tua/ wali siswa. Dan yang terakhir ada bu Mustainah S.Pd.I di bagian media

${ }^{24}$ Hasil wawancara dengan Kabid Kehumasan pada Rabu, 03 Februari 2016

${ }^{25}$ Hasil wawancara dengan Bagian Komite pada Rabu, 03 Februari 2016 
internal, beliau bertugas untuk mengumpulkan semua data kehumasan ke dalam masing-masing pihak tadi seperti media ekternal dan komite sekolah. ${ }^{26}$ Data-data yang didapatkan oleh Ibu Mustainah S.Pd.I akan dikelola menjadi video-video progam-progam kegiatan juga ditampilkan di mading sekolah. Berdasarkan tugas yang telah diberikan kepada masing-masing pihak ada beberapa tugas/ progam yang belum terealisasi secara optimal yaitu pengeloalaan website. Sering sekali bagian koordinator humas menyampaikan kepada para guru bahwa pengajar yang ada di SD IT Harapan Bunda adalah cerminan dari sekolah. Koordinasi dapat diwujudkan dengan cara rapat baik rapat jangka pendek dan rapat jangka panjang. SD IT Harapan Bunda mengadakan rapat jangka pendek dalam artian rapat mingguan yang dilaksanakan setiap hari Jum'at, Sedangkan untuk rapat jangka panjang setiap 6 bulan sekali biasa disebut dengan rapat kerja. Antar pihak humas di SD IT Harapan Bunda juga saling berkoordinasi Jadi, tidak hanya pembentukan organisasi saja tetapi koordinasi antar bagian juga berjalan dengan baik. Terkadang kabid kehumasan mewakili kepala sekolah dalam menyampaikan perintah artinya ketika kepala sekolah sedang ada urusan yang lain itu disampaikan melalui kabid kehumasan baik sms atau media sosial, kemudian kabid kehumasan menyampaikan kepada guru-gurujadi ketika di internal kabid kehumasan kadang menggantikan kepala sekolah. Memberikan pengarahan secara umum kepada para guru dilaksanakan setiap hari Jum'at ketika rapat mingguan menggunakan lisan dan tindakan, baik kegiatan komite sekolah kegiatan kehumasan lainnya maupun tentang kesiswaan, Pelaksanaan kerjasama dengan tokoh masyarakat yaitu dengan mengundang tokoh masyarakat untuk datang dalam acara-acara sekolah dan menjadikan beliau sebagai pembicara. Bentuk kerjasama antara sekolah dengan orang tua/ wali siswa yaitu dengan cara berkomunikasi, berorganisasi dan berkoordinasi. Berkomunikasi mengenai perkembangan anak ketika di sekolah, saling sharing dan memenuhi kebutuhan anak. Kemudian untuk berorganisasi ditunjukkan dengan keterlibatan langsung orang tua/ wali siswa dalam acara sekolah. Berkoordinasi dengan orang tua/ wali siswa ketika pemberitahuan kegiatan ta'lim dan komite dengan cara lisan, surat dan juga whatsapp. ${ }^{27}$ Kemudian ada kegiatan komite sekolah yang rutin dilaksanakan setiap satu tahun dua kali. Pelaksanaan kerjasama dengan organisasi-organisasi masyarakat yaitu dengan rilis ke media-media mengenai even internal maupun eksternal. Publikasi dengan cara memberikan informasi sekolah ketika penerimaan siswa baru berjalan dengan sangat baik sesuai dengan tanggapan orang tua/ wali siswa dengan rerata skala 4,28 .

26Hasil wawancara dengan Kabid Kehumasan pada Rabu, 03 Februari 2016

27 Hasil wawancara dengan Bagian Komite pada Rabu, 03 Februari 2016 
3. Implikasi Manajemen Humas SD IT Harapan Bunda dalam Meningkatkan Hubungan Baik antara Sekolah dengan Wali Siswa

Dari beberapa strategi yang direncanakan dan dilaksanakan manajemen humas SD IT Harapan Bunda dalam meningkatkan hubungan baik antara sekolah dengan wali siswa didapatkan hasil (implikasi) yaitu sangat baik. Hal ini ditunjukkan dengan data rerata skala tanggapan responden dengan jumlah 4,27. Selain itu juga banyaknya kegiatankegiatan bersama orang tua/ wali siswa dalam meningkatkan hubungan baik diantaranya:

a. Seminar parenting/ lainnya

Kegiatan seminar dilaksanakan setiap satu tahun sekali.

b. Lomba antar komite kelas

Lomba ini diadakan setiap 1 tahun sekali. Salah satu lomba yang diadakan yaitu lomba mengolah makanan. ${ }^{28}$

c. Ta'lim

Kegiatan ta'lim merupakan pengajian rutin yang diikuti oleh wali siswa PAUD, TK, SD dan SMP dan juga guru

d. Anjangsana

Anjangsana merupakan kegiatan kunjungan guru ke rumah siswa.Kegiatan ini dilaksanakan setiap dua minggu sekali.

e. Home visit

Kegiatan home visit sama halnya dengan kegiatan silaturahmi anjangsana yaitu kunjungan guru ke rumah siswa, tetapi tujuan home visit adalah menjenguk ketika anak sakit, wali siswa sakit dan melahirkan.

f. Baksos, Bazar dan cek kesehatan gratis

Setiap tahunnya SD IT Harapan Bunda mengadakan Bakti Sosial yang bekerjasama dengan wali siswa. Kegiatan ini diadakan sebanyak 2-3 kali oleh komite sekolah dan komite kelas.

g. Open house

Kegiatan open house adalah mengundang sekolah-sekolah lain untuk datang ke acara yang diadakan oleh SD IT Harapan Bunda. 


\section{Kesimpulan}

1. Strategi humas sekolah merupakan penjabaran dari strategi sekolah dalam mencapai tujuan strategisnya. Strategi yang dilakukan manajemen humas SD IT Harapan Bunda diantaranya: Go Public, bekerjasama dengan kesiswaan, penyusunan struktur organisasi, menggerakkan anggota-anggota organisasi dan berkoordinasi dalam mencapai tujuan yang ditetapkan lembaga, pengarahan kepada personel sekolah, pengawasan kepada personel sekolah, bekerjasama dengan tokoh masyarakat, bekerjasama dengan orang tua/ wali siswa, bekerjasama dengan komite sekolah, bekerjasama dengan organisasi-organisasi masyarakat, publikasi.

2. Implementasi manajemen humas di SD IT Harapan Bunda yaitu hampir seluruh strategi yang direncanakan ada kerjasama antara pihak internal maupun pihak eksternal. Hal ini ditunjukkan dengan proses pelaksanaan dari strategi yang telah direncanakan tetapi dari satu strategi yang direncanakan ada beberapa progam yang tidak terealisasi secara optimal yaitu pengelolaan website dikarenakan kesibukan dari penanggungjawab progam tersebut.

3. Implikasi manajemen humas dalam meningkatkan hubungan baik antara sekolah dengan orang tua/ wali siswa SD IT Harapan Bunda berjalan dengan sangat baik, hal ini ditunjukkan dengan data rerata skala tanggapan responden dengan jumlah 4,27. Selain itu juga banyaknya kegiatan-kegiatan bersama orang tua/ wali siswa dalam meningkatkan hubungan baik. 


\section{Daftar Pustaka}

Aminatun, Siti (2014), Kontribusi Manajemen Hubungan Masyarakat (Humas) Dalam Meningkatkan Kepercayaan Wali Siswa Kepada SDIT Giwangan Yogyakarta. Yogyakarta: Perpustakaan STAIT Yogyakarta

Arikunto, Suharsimi (2013), Manajemen Penelitian. Jakarta: PT Rineka Cipta

Depdiknas UU RI No. 20 Th 2003

Dwi Dayanti, Liestianingsih, Dkk (2014), Hubungan Masyarakat. Tanggerang Selatan: Universitas Terbuka

Dwi Prasetyo, Danang (2011), Pengelolaan Sekolah Islam Terpadu dalam Prespektif Administrasi Pendidikan. Hand Out Administrasi Supervisi Pendidikan STAIT

Irianta, Yosal (2013), Manajemen Humas Sekolah. Bandung: Simbiosa Rekatama

Nasional, Departemen Pendidikan (2008), Kamus Besar Bahasa Indonesia Pusat Bahasa. Jakarta: PT. Gramedia Pustaka Utama

Nasution, Zulkarnain (2010), Manajemen Humas di Lembaga Pendidikan. Malang: UMM Press

Pidarta, Made (1988), Manajemen Pendidikan Indonesia. Jakarta: PT Bina Aksara Jakarta

Qomar, Mujamil (2007), Manajemen Pendidikan Islam. Jakarta: Penerbit Erlangga

Sugiyono (2013), Metode Pendidikan Pendekatan Kuantitatif, Kualitatif, dan $R \mathcal{E D}$. Bandung: Alfabeta

Suryabrata, sumadi (2005), Metode Penelitian. Jakarta: PT Raja Grafindo Persada

Suryosubroto, B (2001), Humas Dalam Dunia Pendidikan. Yogyakarta: Mitra Gama Widya

Syaodih Sukmadinata, Nana (2013), Metode Penelitian Pendidikan. Bandung: PT Remaja Rosdakarya

Usman, Husaini (2008), Manajemen Praktik E Riset Pendidikan. Jakarta Timur: Sinar Grafika Offset

http://lib.uin-malang.ac.id/files/thesis/fullchapter/00160043.pdf diakses pada Jum'at, 09/10/2015 jam 14.20 WIB

http://sditharapanbunda.blogspot.co.id diakses pada Senin, 21/03/2016 jam 09.46 WIB 